\title{
Current Account and Real Exchange Rate Dynamics in Indonesia
}

\author{
Firman Mochtar ${ }^{a}$, Yoga Affandia,* \\ ${ }^{a}$ Bank Indonesia
}

\begin{abstract}
We analyzed the role of both permanent and temporary factors in affecting the Indonesian current account and real exchange dynamics before and after 2000. Adopting Lee and Chinn $(1998 ; 2006)$ approach as well as Chinn et al. (2007), two results stand out. First, we confirm that the behavior of the real exchange rate has altered since 2000. Identifications show that permanent shocks have been the primary causes for the movement of the real exchange rate after 2000, while in the period before 2000, Indonesia's real exchange rate changes were characterized by greater dominance of temporary shocks. The apparent change in the real exchange rate behavior may be strongly justified by the implementation of free-floating exchange rate system since August 1997. Second, the shift of the real exchange rate behavior after 2000 has not necessarily affected the current account dynamics. Empirical evidence confirms that the variance in current account post 2000 remains largely due to temporary shocks. Albeit having increasing influence, permanent shocks have insignificant effect in explaining fluctuations of the current account. In this sense, the current account surplus after 2000 has been attributed largely to nominal variables such as price increase, while the impact of productivity improvement is still limited.
\end{abstract}

Keywords: Current Account; Real Exchange Rate; Asian Crises 1997/1998

\begin{abstract}
Abstrak
Kami menganalisa peranan faktor permanen dan temporer dalam memengaruhi neraca berjalan dan dinamika nilai tukar mata uang riil Indonesia sebelum dan setelah tahun 2000. Mengadopsi pendekatan Lee dan Chinn (1998; 2006) serta Chinn et al. (2007), telah diperoleh dua kesimpulan. Pertama, kami mengonfirmasi bahwa pola nilai tukar mata uang riil telah berubah sejak tahun 2000. Identifikasi menunjukkan bahwa shock permanen adalah penyebab utama pergerakan nilai tukar mata uang riil setelah tahun 2000, sedangkan di periode sebelum tahun 2000 perubahan nilai tukar mata uang riil dicirikan oleh dominansi shock temporer. Perubahan pola nilai tukar mata uang tersebut dapat berakar dari penerapan sistem nilai tukar mengambang bebas sejak Agustus 1997. Kedua, perubahan pola nilai tukar mata uang setelah tahun 2000 tidak serta merta memengaruhi dinamika neraca berjalan. Bukti empiris mengonfirmasi bahwa variansi neraca berjalan setelah tahun 2000 tetap disebabkan utamanya oleh shock temporer. Meskipun menunjukkan peningkatan pengaruh, shock permanen memiliki pengaruh yang tidak signifikan dalam menjelaskan fluktuasi neraca berjalan. Dengan kata lain, surplus neraca berjalan setelah tahun 2000 dapat diatribusikan kepada variabel nominal seperti kenaikan harga, sedangkan pengaruh peningkatan produktivitas masih cenderung terbatas.
\end{abstract}

Kata kunci: Neraca Transaksi Berjalan; Nilai Tukar Riil; Krisis Asia 1997/1998

JEL classifications: F31; F41

\section{Introduction}

There have been significant differences when comparing Indonesia's current account dynamics be-

\footnotetext{
*Corresponding Address: M.H. Thamrin Street, No. 2, Jakarta 10350, Telp. +62-21-500-131. E-mail: yogaf $f @ b i . g \circ$. id.
}

fore and after the 1997/98 Asian economic crisis. Prior to 1998 , Indonesia's current account had typically run in deficit, reaching close to $3 \%$ of GDP (Figure 1). Nevertheless, the country's current account shifted into surplus after 1998 and hitting a record of $2.5 \%$ of GDP in 2004 before shrinking back to deficit of $2.7 \%$ of GDP in 2012 . 


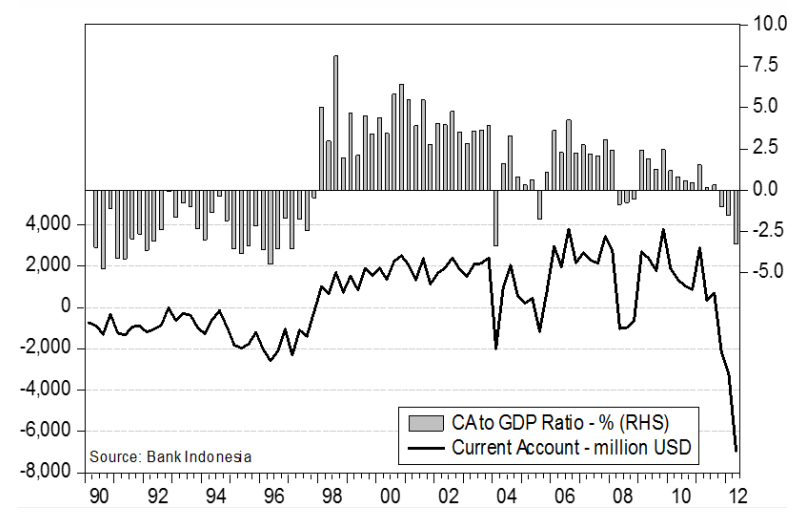

Figure 1: Indonesia's Current Account

What component caused the current account to shift after the 1998 crisis? Given the services account has been persistently deficit since the Asian Crisis, one explanation therefore lies on the trade balance. Data depicted that Indonesia's trade balance surplus over the last decade was mainly related to the strong commodity exports. However, when the commodity price boom went into bust in 2012, the surplus narrowed. Meanwhile, in noncommodity trade balance, imports have surpassed exports since 2006, making the small surplus turned into deficit with the tendency to grow larger. Two main reasons are behind this: the weakening performance of export notably in manufacturing sector and high import growth due to strong domestic demand.

Another approach to explain current account dynamics is that there is either permanent or temporary factor behind the current account behaviour. Questions arises when we relate them to the fact that structural changes have shifted the Indonesian socio-economic and political landscapes after the 1997/98 crisis. As illustration, Bank Indonesia has adopted a free-floating exchange rate system since August 1997 and implemented inflationtargeting as the framework for monetary policy in 1999 (Ananta et al. 2011). Furthermore, on fiscal policy, the government has committed to fiscal consolidation, aimed at a sustainable budget and implemented fiscal decentralization since 1999. In general, it is reasonable to suggest that the aforesaid changes may affect current account dynamics post-1997/98 crisis.

This study attempts to reveal the latter approach, i.e. to investigate the relationship between struc- tural changes in Indonesia and the shift in current account patterns in the periods before and after the Asian crisis. For that purpose, we will classify probable factors affecting current account dynamics into two specific groups: permanent and temporary factors. Permanent factors are the ones structurally affecting current account in the long term such as the supply side, productivity, as well as changes in preferences. Clarida and Gali (1994) denoted shocks in these structural factors as real shocks, that eventually affect supply side of the economy such as natural disaster or technology. On the other hand, temporary factors are those that affect current account only in the short run such as nominal variables like prices, money supply, and nominal exchange rate.

By adopting Lee and Chinn (1998; 2006), this study has supported two main conclusions. First, real exchange rate behavior, as a factor affecting current account, has significantly changed after 2000. Post-2000, it is evidenced that real exchange rate behavior has been mainly affected by permanent factors, whereas prior to 2000, temporary factors played dominant role. Moreover, it is strongly suggested that the adjustment of real exchange rate behavior was affected by implementation of free-float exchange rate regime and inflation targeting framework. Under this policy framework, the role of central bank in foreign exchange market is minimal so that the exchange rate will move according to economic fundamentals. That said, real exchange rate behavior after 2000 was mainly influenced by structural and fundamental changes, rather than nominal factor movement.

On the other hand, as the second conclusion, 
the shift in exchange rate behavior post 2000 did not necessarily affect the current account behavior. Identifications showed that current account behavior after 2000 remains due to the dominant role of temporary variables. The role of permanent factors, despite having been intensified, remain smaller than temporary factors in affecting current account dynamics post-2000. Therefore, we can infer that the current account surplus post2000 has been affected more by nominal factors like price level rather than productivity improvement. Accordingly, deterioration of nominal factors will fade the surplus away.

This paper will be divided into four parts. The second part will outline the theoretical considerations and empirical testing methods. The third part will present estimation results on the dynamic role of permanent and temporary factors in affecting real exchange rate and current account in 1990-2012. Furthermore, this section will lay out the impact of historical behaviour of both factors on current account and real exchange rate. The final part offers the conclusion.

\section{Literature Review}

We adopt Lee and Chinn (1998; 2006) approach in modeling the impact of permanent and temporary factors on current account dynamics and real exchange rate. The working model is based on Clarida and Gali (1994) with two variables, namely the current account and the real exchange rate. In this approach, both permanent and temporary factors are approximated by permanent and temporary variables and yet shocks at each variable will be classified as real shock and nominal shock, respectively.

Following Lee and Chinn (1998), the economy is built based on standard IS-LM model. Equation (1), as the IS equation, explains how real exchange rate $\left(s_{t}-p_{t}\right)$ and expectation on real interest rate $\left(i_{t}-E_{t}\left(p_{t+1}-p_{t}\right)\right)$ affect demand for output $\left(y_{t}^{d}\right)$. Meanwhile, equation (2) shows the demand for real money $\left(m_{t}-p_{t}\right)$ as a function of output $\left(y_{t}\right)$ and nominal interest rate $\left(i_{t}\right)$. Equation (3) is the expression for the interest rate parity, which states that nominal interest rate is determined by the difference between exchange rate at time $t\left(s_{t}\right)$ and market expectations of future exchange rate $\left(s_{t+1}\right)$.
Furthermore, equation (4) presumes that the price level $\left(p_{t}\right)$ will move gradually toward its long run equilibrium $\left(p_{t}^{e}\right)$.

$$
\begin{gathered}
y_{t}^{d}=\eta\left(s_{t}-p_{t}\right)-\sigma\left(i_{t}-E_{t}\left(p_{t+1}-p_{t}\right)\right) \\
m_{t}-p_{t}=y_{t}-\lambda i_{t} \\
i_{t}=E_{t}\left(s_{t+1}-s_{t}\right) \\
p_{t}=(1-\theta) E_{t-1} p_{t}^{e}+\theta p_{t}^{e}
\end{gathered}
$$

Finally, the model will be complemented by three other equations as follows:

$$
\begin{gathered}
y_{t}^{s}=y_{t-1}^{s}+z_{t} \\
m_{t}=m_{t-1}+v_{t} \\
b_{t}=\xi\left(s_{t}-p_{t}\right)+\rho z_{t}
\end{gathered}
$$

Equation (5) suggests that the rise in productivity $z_{t}$, as a real shock, will induce domestic economy to outperform relative to foreign countries. Meanwhile, Equation (6) describes stochastic process of the money supply as a nominal variable whereas Equation (7) specifies the current account as a function of real exchange rate $\left(q_{t}=s_{t}-p_{t}\right)$ and economic productivity.

In brief, as shown in Lee and Chinn (1998), analytical derivation of Equation (1) infers that under flexible price, the neutrality of nominal shocks will hold on real exchange rate in the long-run. Accordingly, contribution of nominal shocks in explaining current account is abolished in the long run. Meanwhile, in the short run where the price is not flexible, analytical result shows that the money supply increase will depreciate the currency, as described in Equation (9). Furthermore, Equation (9) implies that in the short run, increase in nominal shock will revamp the current account, as routed in Equation (7).

$$
\begin{gathered}
q_{t}=\frac{y^{s}}{\eta}+\mu(1-\theta)\left(v_{t}-z_{t}\right) \\
\text { where } \mu \equiv \frac{1+\lambda}{\lambda+\sigma+\eta} \\
\text { So that } \frac{\partial q_{t}}{\partial v_{t}}>0 \text { for } \theta<1
\end{gathered}
$$




$$
\begin{gathered}
\frac{\partial q_{t}}{\partial\left(-z_{t}\right)}=-\frac{1}{\eta}+\mu(1-\theta) \\
\frac{\partial q_{t}}{\partial\left(-z_{t}\right)}=-\frac{1}{\eta}
\end{gathered}
$$

It is also possible to infer from Equation (8) that the effects of technological shock, as a form of real shock, will result in two possible outcomes. However, outcome will vary according to sensitivity of real exchange rate to output and degree of price flexibility, as stated in Equation (10). Under a very flexible price $(\theta \cong 1)$, negative productivity shock (or positive productivity shock to foreign economy) will improve the real exchange rate, and vice versa. However, with price rigidity, negative productivity shock will only worsen the real exchange rate.

If we put together Equations (1) and (5), we can infer that negative productivity shock will appreciate the real exchange rate in the long run, as indicated in Equation (11). Meanwhile, from Equation (7) we can infer that the impact of negative productivity shock on current account is ambiguous, both in the short run and the long run.

\section{Method}

From the above settings, we estimate a bivariate VAR of real exchange rate $\left(q_{t}\right)$ and ratio of current account to GDP $\left(b_{t}\right)$ by imposing long run Blanchard and Quah (1989) restrictions to distinguish between nominal $\left(\epsilon_{t}^{P}\right)$ and real shocks $\left(\epsilon_{t}^{T}\right)$ as follows:

$$
\begin{aligned}
{\left[\begin{array}{c}
\Delta q_{t} \\
b_{t}
\end{array}\right]=} & B(L)\left[\begin{array}{c}
\Delta q_{t} \\
b_{t}
\end{array}\right]+\left[\begin{array}{l}
\varepsilon_{t}^{q} \\
\varepsilon_{t}^{b}
\end{array}\right] \\
= & B(L)\left[\begin{array}{c}
\Delta q_{t} \\
b-t
\end{array}\right]+B(0)\left[\begin{array}{c}
\epsilon_{t}^{p} \\
\epsilon_{t}^{T}
\end{array}\right]
\end{aligned}
$$

As in Fackler and McMillan (1998), Equation (12) can be historically decomposed by transforming the VAR into Vector Moving Average (VMA) so that the reduced-form shocks $\left(\varepsilon_{t}\right)$ are also transformed into structural shocks $\left(\epsilon_{t}\right)$. Each variable in our VAR system is then decomposed into deterministic and stochastic components whereas the stochastic component or total components shock is further decomposed into permanent and temporary shocks.
The deterministic component can be interpreted as a time-invariant variable, thus it tends to converge to constant value in the long run. This component is obtained from the elimination of permanent and temporary shock. Impact of permanent shock is attributed only to permanent variables while temporary variables react only to temporary shocks. That being said, the deterministic value of current account is the-long run ratio obtained when both permanent and temporary shocks are eliminated. The permanent current account is obtained when only structural factors are considered. The permanent real exchange rate should be viewed as the reflection of fundamental factors, in which only structural factors affect the exchange rate, while temporary factors such as market sentiment play no role.

\section{Result and Analysis}

\subsection{Data}

We use quarterly data both for current account to GDP ratio and the log of real exchange rate. Using the period of 1990:1-2012:2, both variables are seasonally adjusted using X-12 method. Real exchange rate is constructed as a weighted average of bilateral exchange rate of US, Japan and Euro countries, as major trading partners. Unit root testing on real exchange rate (q) and current account (b) requires real exchange rate to be I(1) and the current account to be I(0), respectively. Stationarity test is conducted based on Augmented Dickey Fuller test while 3 period lag lengths for the VAR is chosen based on Akaike Information Criteria (AIC).

To capture any possible impact of structural changes in real exchange rate and current account, first empirical test is done for all sample of 1990-2012. Afterwards, empirical analysis is implemented by dividing the sample into two subsamples covering pre-2000 (1990-1999) and post2000 (2000-2012). Similar approach is done by Shibamato and Kitano (2012) in order to identify the relationship between current account dynamics and real exchange rate for $\mathrm{G} 7$ countries. 
Response to Structural One S.D. Innovations

(a) Response of RER to Temporary Shock

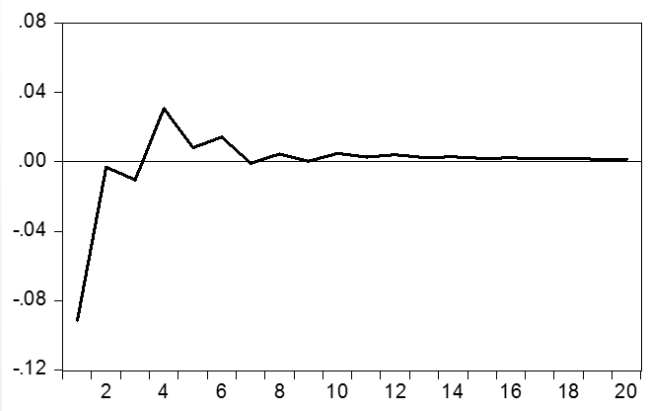

(b) Response of RER to Permanent Shock

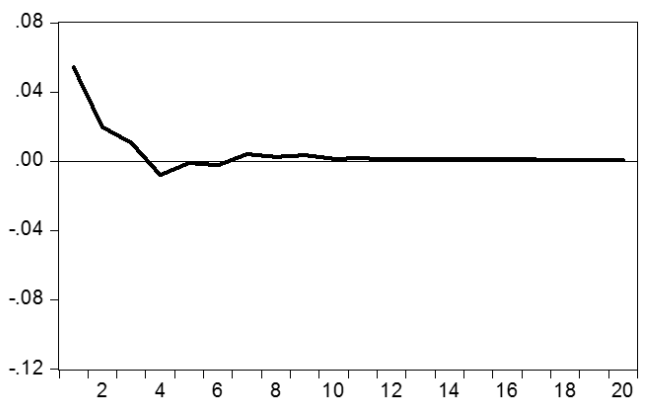

Figure 2: (a) Response of Real Exchange Rate to Temporary Shock; (b) Response of Real Exchange Rate to Permanent Shock

\subsection{Impulse-Response Function Anal- ysis}

Impulse-response function (IRF hereafter) shows that our data is broadly consistent with our theoretical background. From Figure 2a, we can observe that for the full sample of 1990-2012, temporary shock -representing nominal shock- will weaken the real exchange rate in the short run and lasts until 4 quarters. Meanwhile, Figure $\mathbf{2 b}$ demonstrates that when price rigidity is present, the increase in permanent shock as real disturbances will likely to strengthen the real exchange rate for up to 4 quarters.

IRF analysis of current account for the full sample of 1990-2012 also confirms the theoretical prediction. Figure 3a exhibits the impact of temporary shock through nominal disturbances has increased the current account surplus. In this case, the rise of the current account surplus can also be explained by the permanent shock component as shown in Figure $\mathbf{3 b}$. Referring to Equation (7), evidences as in previous figures indicate that increased productivity explains current account surplus more dominantly than the strengthened real exchange rate.

Moreover, Figure $\mathbf{4 a}$ and $\mathbf{4 b}$ display the IRFs for subsamples of pre- and post-2000. Evidently, the effects of temporary and permanent shocks in both sample groups are unchanged and consistent with the theory. As in the whole sample group, a temporary shock causes deterioration of real exchange rate and improves the current account in both preand post-2000 (Figure 4a). Additionally, IRFs in both sample groups continue to depict strengthened real exchange rate and increased current account surplus in the event of permanent disturbances as shown in Figure 4b.

\subsection{Variance and Historical Decompo- sitions of Real Exchange Rate}

Having confirmed the empirical result to the analytical approach, in this section, we perform variance decomposition analysis to investigate factors affecting real exchange rate and the current account behaviour. For the first case, we investigate the full sample of 1990-2012. Empirical evidence shows that for the full sample period, the Indonesian real exchange rate is largely influenced by nominal variables. This fact is observed in the importance of temporary shock in affecting the variance of the real exchange rate. Variance decomposition results depict that temporary shock accounts for $75 \%$ of the variance of the real exchange rate (Figure 5).

Nevertheless, variance decomposition displays different results in pre- and post-2000 periods. Prior to 2000 , temporary shock accounted for $90 \%$ of the variance in real exchange rate (Figure 6a), whereas permanent shock has dominated real exchange rate movements after 2000 (Figure 6b).This significant shift can be appropriately explained by the impact of implementation of freefloating exchange rate regime as well as the implementation of inflation-targeting framework. In the aforesaid systems, central bank intervention in the 
Response to Structural One S.D. Innovations

Response of CA to Tem porary Shock

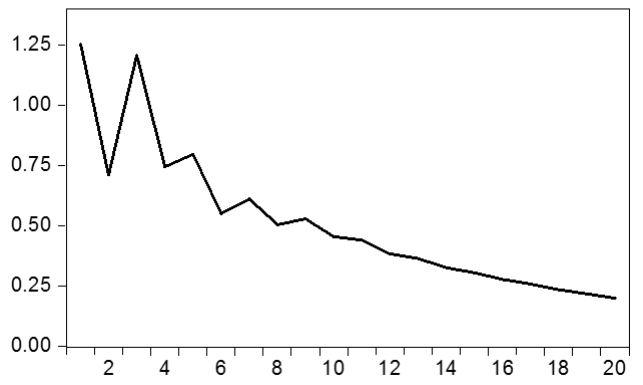

Response of CA to Permanent Shock

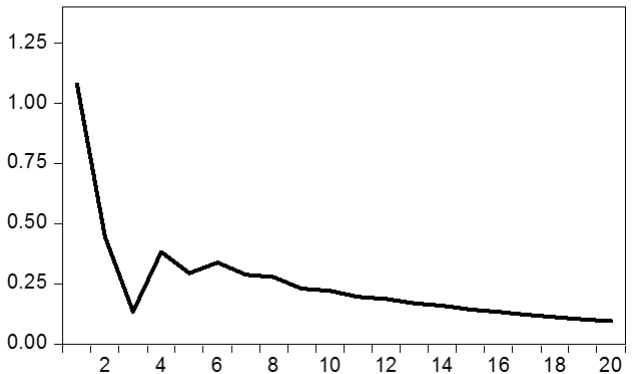

Figure 3: (a) Response of Current Account to Temporary Shock; (b) Response of Current Account to Permanent Shock

(a). Pre 2000

Temporary Shock

Permanent Shock

Response to Stuctural One S.D. Innovations

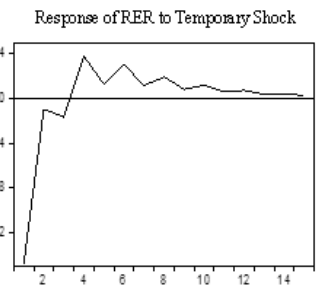

Resporse of $\mathrm{CA}$ to TemporaryShock

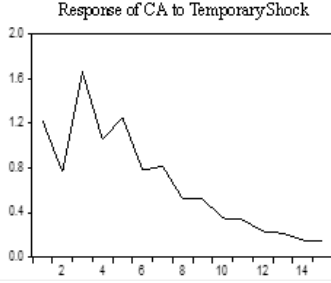

Resporse of RER to Permanent Shock

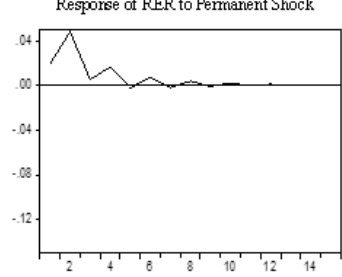

Response of $\mathrm{CA}$ to Permanent Shock

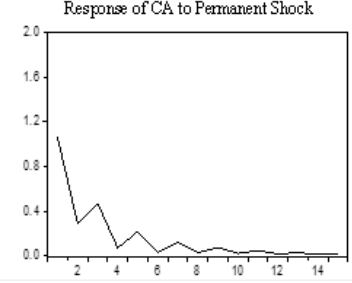

(b). Post 2000

Temporary Shock

Permanent Shock

Response to Stuctural One S.D. Innovations
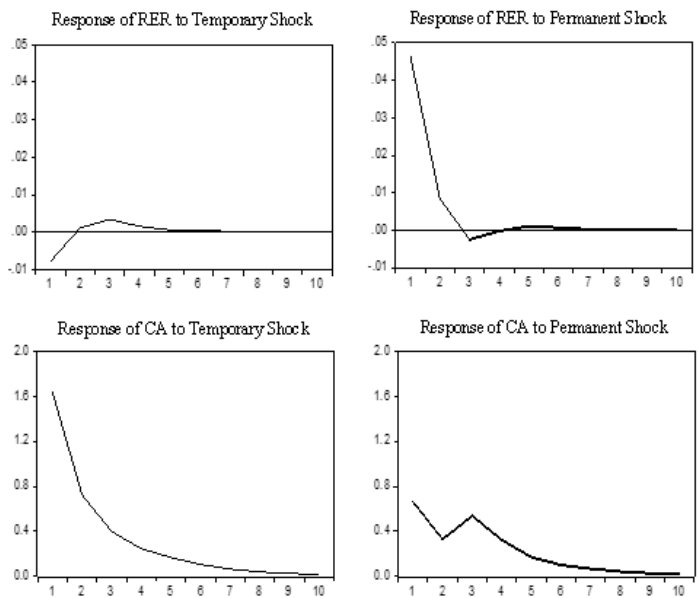

Figure 4: (a) Response of RER and CA to Temporary Shock, Pre-2000;

(b) Response of RER and CA to Temporary Shock, Post-2000 Source: Author's calculation

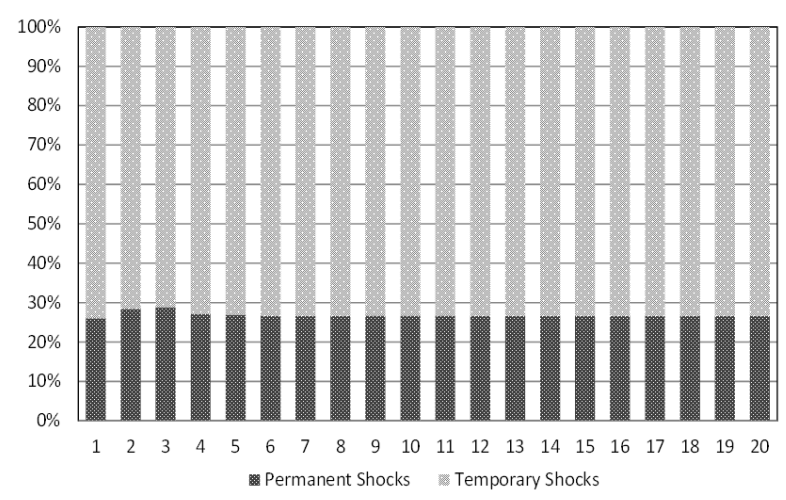

Figure 5: Variance Decomposition: Real Exchange Rate, Full Sample Source: Author's calculation

Economics and Finance in Indonesia Vol. 61 No. 2, August 2015 
(a) Variance Decomposition RER, Pre 2000

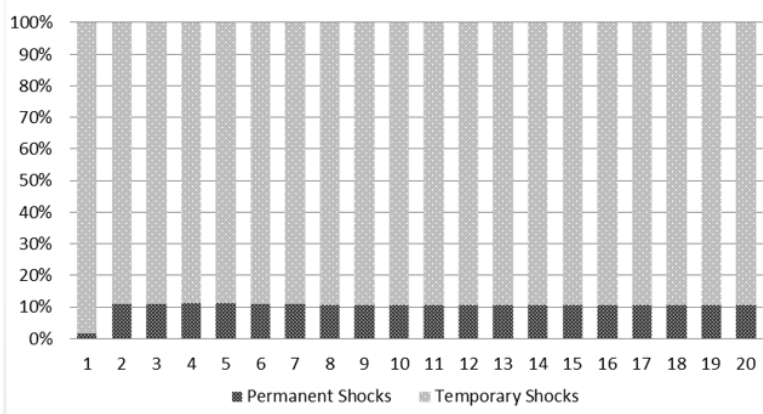

(b) Variance Decomposition RER, Post 2000

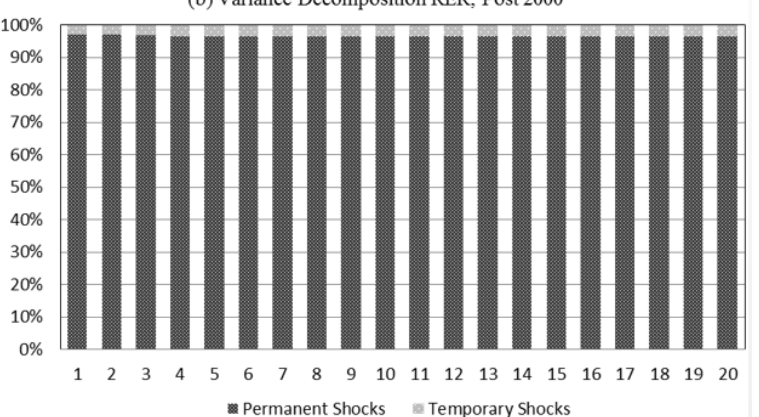

Figure 6: (a) Variance Decomposition: Real Exchange Rate, Pre-2000;

(b) Variance Decomposition: Real Exchange Rate, Post-2000

Source: Author's calculation

exchange rate market is minimal, so that exchange rate is maintained at rates that are consistent with economic fundamentals.

Changes in the dominating factor of real exchange rate dynamics after 2000 are also confirmed by historical decomposition analysis. From Figure 7a, we can observe that the impact of temporary shock dominated the real exchange rate prior to 2000. Meanwhile, after 2000 , the role of permanent shock is the dominant source behind the real exchange rate movement for almost the entire sample period. In contrast, the role of temporary shock has appeared only in certain period in small magnitude (Figure 7b).

\subsection{Variance and Historical Decompo- sition of Current Account}

Another outcome that needs to be focused to is the leading role of temporary shocks in explaining the current account dynamics. As shown in Figure 8, variance decomposition for full sample period (1990-2012) shows that temporary shocks have accounted for $60 \%$ of the variance of current account during the first two quarters and increased to $75 \%$ afterwards. Accordingly, permanent shocks have accounted only for $40 \%$ of variance in current account in early observation period before subsequently shrinking to $25 \%$.

Plots of variance decomposition for current account for pre and post-2000 is presented in Figure 9. Notably, temporary shocks track $85 \%$ of the variance of the current account after 7 periods in the pre-2000 sample group (Figure 9a). Furthermore, the variance of the current account has still been dominated by temporary shocks albeit its declining impact to $78 \%$ in the period of post-2000 (Figure 9b). This evidence can imply that the size of permanent shocks after 2000 tend to grow up to $22 \%$. Nevertheless, while the variance of current account captures a growing impact of the permanent shock, as a representation of real shock, nominal shock has remained as the dominant forces in explaining current account variance post 2000.

We now turn to the historical decomposition results for the response of current account to temporary shocks. Before 2000, temporary shocks played dominant role throughout the sample period, while permanent shocks had a very minimal impact in explaining the current account (Figure 10a).This behavior seems to continue for the post 2000. As evident in Figure 10b, temporary shocks have still played the leading role in the current account dynamics in Indonesia after 2000, despite some indication of increasing impact of permanent shocks in explaining the variance of the current account in 2009-2011.

\section{Conclusion}

The purpose of this study is to asses the possible impact of structural changes on the dynamics of Indonesia's current account and real exchange rate before and after the Asian 1997/98 crises. Consistent with Lee and Chinn (1998; 2006) approach as well as Chinn et al. (2007), it is evident that permanent shock -as a reflection of real or produc- 

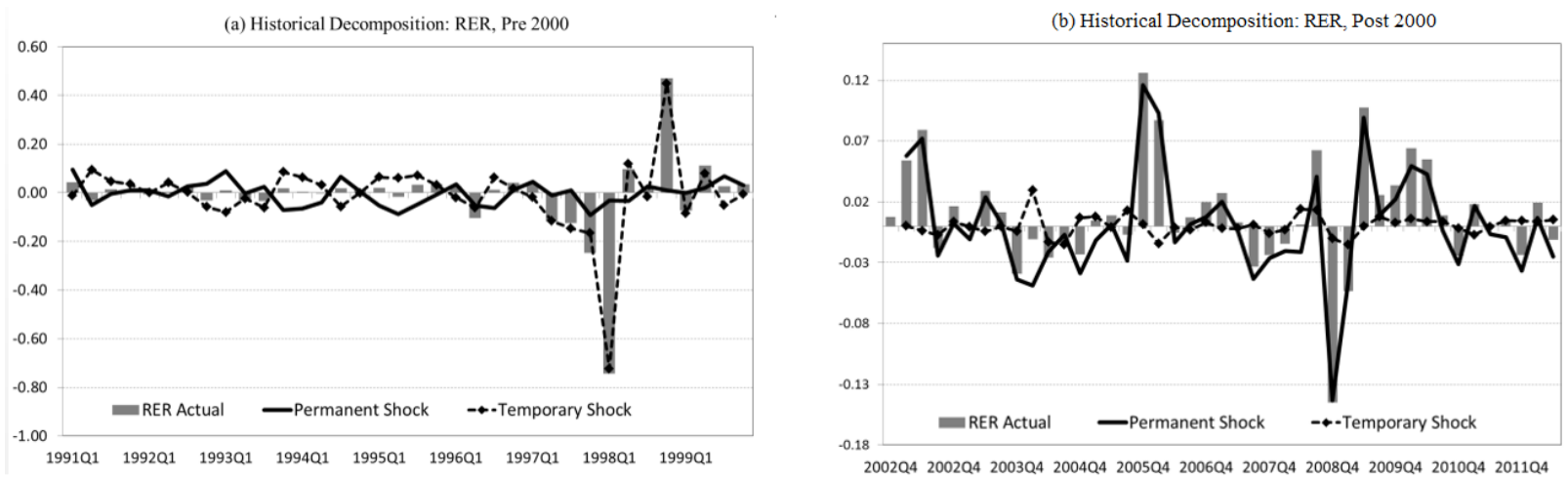

Figure 7: (a) Historical Decomposition: RER, Pre-2000;

(b) Historical Decomposition: RER, Post-2000

Source: Author's calculation

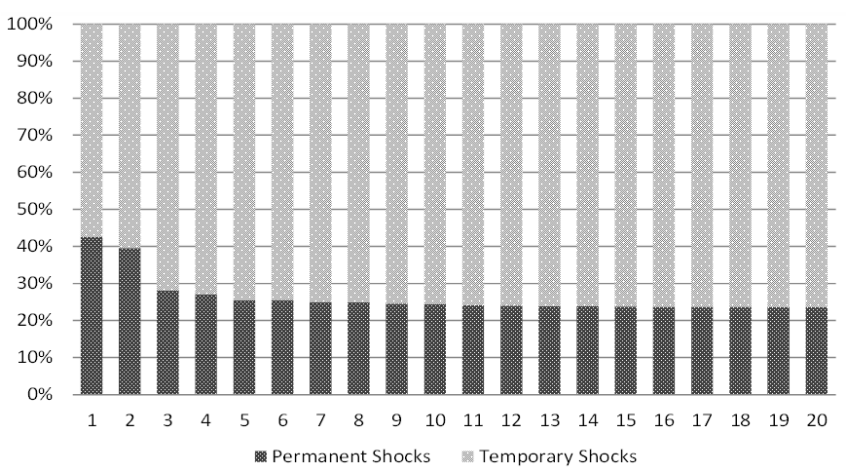

Figure 8: Variance Decomposition: Current Account, Full Sample Source: Author's calculation

(a) Variance Decomposition CA, Pre 2000

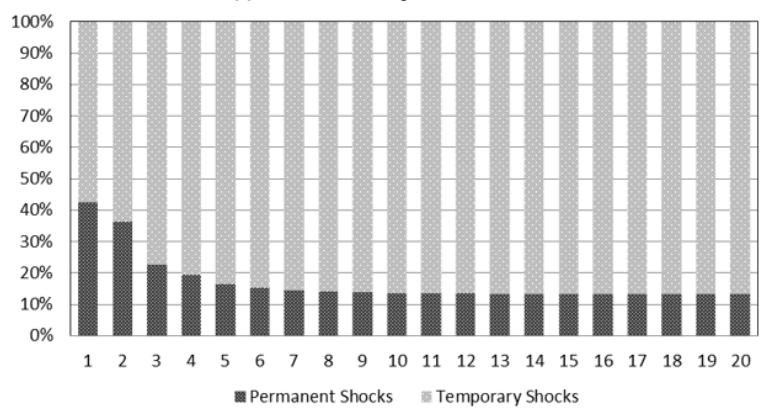

(b) Variance Decomposition CA, Post 2000

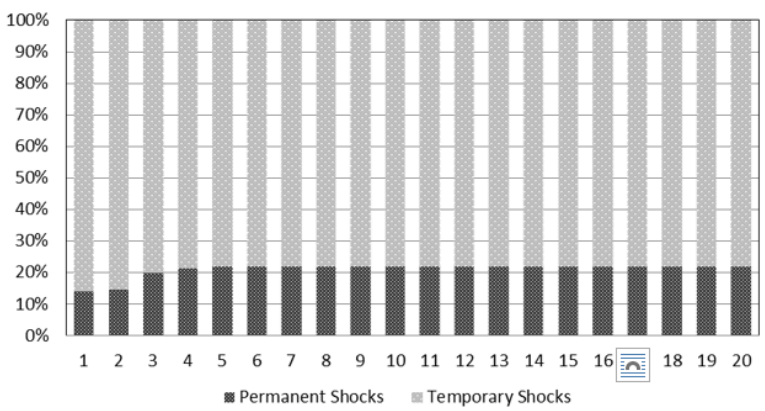

Figure 9: (a) Variance Decomposition: Current Account, Pre-2000;

(b) Variance Decomposition: Current Account, Post-2000 Source: Author's calculation 

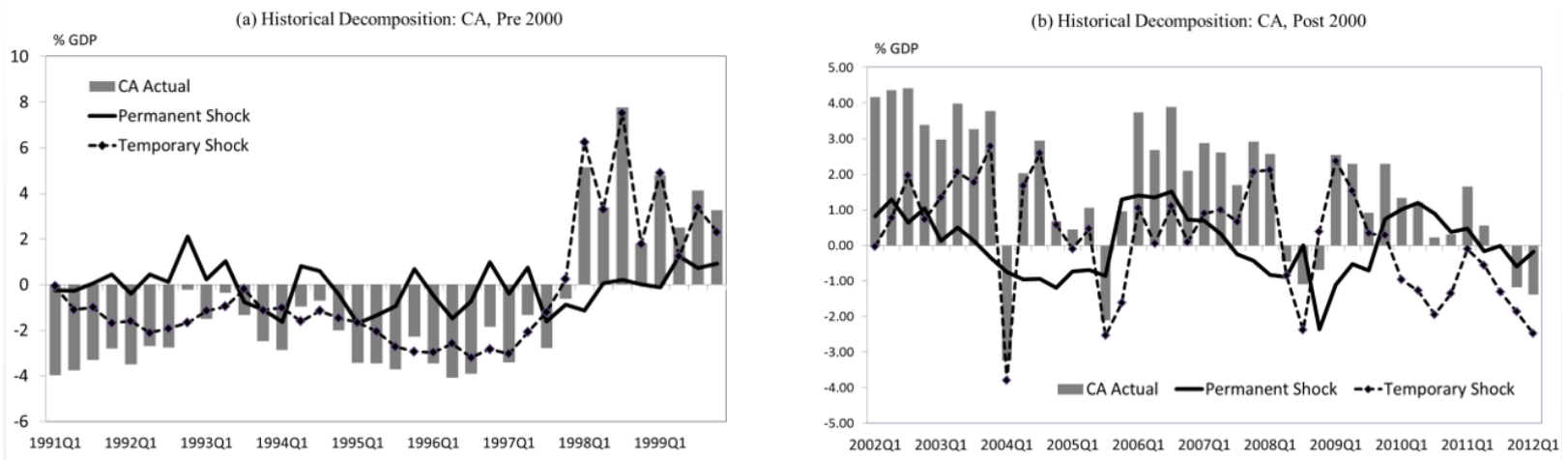

Figure 10: (a) Historical Decomposition: Current Account, Pre-2000;

(b) Historical Decomposition: Current Account, Post-2000

Source: Author's calculation

tivity shock- creates current account surplus, coupled with real exchange rate improvement. Conversely, decreased productivity will suppress the current account surplus and deteriorate the real exchange rate. The paper also finds that temporary shock -as a reflection of nominal shock- at one hand drives the current account surplus while on the other hand worsening the real exchange rate.

Based on those relationships, two results stand out. First, behavior of the real exchange rate has altered since 2000. Identifications show that permanent shocks have been the primary causes for the movement of the real exchange rate after 2000, which is different from the behavior prior to 2000 where temporary shocks played dominant role. The apparent change in the real exchange rate behavior is plausible justified by the impact of the implementation of free-floating exchange rate system since August 1997.

Accordingly, the shift of the real exchange rate behavior after 2000 does not necessarily affect the current account dynamics. This rises as the second result. Empirical evidence confirms that the variance of current account post-2000 has been largely due to temporary shocks. In contrast, permanent shock has insignificant effect in explaining fluctuations of the current account, albeit a small increasing of permanent shock has been documented. Thus, the empirical evidences support the greater dominance of temporary shocks in affecting the variance of the current account after 2000. In this sense, the current account surplus after 2000 is attributed largely to nominal variables such as price increase while the role of productivity im- provement remains limited. Indonesian current account reacts strongly to price movement so that large negative nominal shock mostly explains the shrinking of current account, as described in the recent trend.

\section{References}

[1] Ananta, A, Soekarni, M \& Arifin, S (Eds.) 2011, The Indonesian Economy: Entering A New Era, Institute of Southeast Asian Studies.

[2] Blanchard, OJ \& Quah, D 1989, 'The Dynamic Effects of Aggregate Demand and Supply Disturbances', The American Economic Review, vol. 79, no. 4, 655-73. September.

[3] Chinn, MD, Lee, J \& La Follette, RM 2007, 'Three Current Account Balances: A "Semi-Structuralist" Interpretation', SCCIE Working Paper \#07-14, Santa Cruz Center for International Economics. Santa Cruz Institute for International Economics, California, USA.

[4] Clarida, R \& Gali, J 1994, 'Sources of Real Exchange Rate Fluctuations: How Important are Nominal Shocks?', CEPR Discussion Papers 951, Centre for Economic Policy Research, London.

[5] Fackler, JS \& McMillan, WD 1998, 'Historical Decomposition of Aggregate Demand and Supply Shocks in Small Macro Mode', Southern Economic Journal, vol. 64, no. 3, 648-664.

[6] Lee, J \& Chinn, MD 1998, 'The Current Account and The Real Exchange Rate: A Structural VAR Analysis of Major Currencies', NBER Working Paper 6495. National Bureau of Economic Research. Available from: <http://www. nber. org/papers/w6495.pdf> [Accessed May 2013].

[7] Lee, J \& Chinn, MD 2006, 'Current Account and Real Exchange Rate Dynamics in the G7 Countries', Journal of International Money and Finance, vol. 25, no. 2, 257-274.

[8] Shibamato, M \& Kitano, S 2012, 'Structural Change in Current Account and Real Exchange Rate Dynamics: Evidence from the G7 Countries', RIEB Discussion Paper Series DP2010-23, Kobe University, Japan. Available from: <http: //www.rieb.kobe-u.ac.jp/academic/ $\mathrm{ra} / \mathrm{dp} /$ English/DP2010-23.pdf> [Accessed May 2013]. 